\title{
Entrepreneurial Learning Design in Higher Education in the Era Revolution Industry 4.0
}

\author{
$1^{\text {st }}$ Tri Suratmi, \\ Business Administration Study \\ Program, Graduate Program of \\ Universitas Respati Indonesia \\ Jakarta, Indonesia \\ tri2209@yahoo.co.id
}

\author{
$2^{\text {nd }}$ Ig A. Wirawan Nugrohadi, \\ Business Administration Study \\ Program, Graduate Program of \\ Universitas Respati Indonesia \\ Jakarta, Indonesia \\ ignatiuslegioner@gmail.com
}

\author{
$4^{\text {th }}$ Nurminingsih \\ Business Administration Study \\ Program, Graduate Program of \\ Universitas Respati Indonesia \\ Jakarta, Indonesia \\ nings_fia@yahoo.co.id
}

$3^{\text {rd }}$. Dinni Agustin

Business Administration Study Program, Graduate Program of Universitas Respati Indonesia Jakarta, Indonesia dinniagustin126@yahoo.com

\begin{abstract}
The disruption era that initiated the 4.0 revolution has caused some types of jobs and professions in Indonesia disappear, replaced by machines/applications with artificial intelligence technology. These conditions force universities to change the orientation of producing ready-to-work human resources, to produce human resources ready to create jobs for themselves and others. Therefore, the urgent change is on the curriculum and its implementation through learning strategies. This paper is a development of entrepreneurship learning concept in university with system approach. The study used is explanatory, with the aim of inspiring the role of university management to provide a conducive academic atmosphere to develop the entrepreneurial spirit of students and lecturers. Entrepreneurship courses are made into compulsory subjects with learning achievements relevant to the profile of graduates in each course. The study materials are arranged referring to the learning achievement, with emphasis on the learning experience that is able to build entrepreneurial mentality such as: 1) preneur tour, 2) expo, 3) collaboration, 4) success story, and 5) organization. Learning strategy using student centered learning approach, by utilizing information and communication technology. Support system required from university management is academic regulation, expo facility, and environment preneur. Evaluate learning by assessing output. Conclusion: the implementation of entrepreneurial learning requires adequate means to support the learning process, and study materials should be up-dated according to changing circumstances.
\end{abstract}

Keywords-- change, empower, entrepreneurship

\section{INTRODUCTION}

The labor force of college graduates is illustrated by the large number of students enrolled in various types of universities in Indonesia. According to statistical data released by Ministry of Research and Technology of Higher Education (Kemenristek Dikti) in 2017, there are 1,437,425 new students, with the number still registered as a student of 6,924,511 students, as for students who graduated 1,046,141 students, spread in Sumatra 218,057 students, in Java 627,191 students, in Kalimantan 48.206 students, in Sulawesi 92,722 students, in Bali-NTT-NTB 40,891 students, and in Maluku 7,462 students. The large number of college graduates has become a problem for the Government to provide jobs. ${ }^{[1]}$

Until now, universities are still an institution coveted by the community as a vehicle to prepare a person's skills to achieve a profession in the world of work. In fact, one of the measures used to assess college rankings is the absorption of graduates in the labor market within 6 (six) months after graduation. But the paradigm will soon change with rapid changes in all fields as a result of technological advances that lead to an era of confusion (disruption) for many circles. Current college graduates are required to be able to create jobs for themselves, because many professions that are expected to be achieved by taking a course in higher education, suddenly erased by change, 
replaced by applications that use artificial intelligence. This condition poses a challenge for university management to reform the curriculum by providing entrepreneurial learning content, and providing a systematic support tool.

Entrepreneurship learning has been done in many universities, especially economic and business colleges that design campus and its learning programs are directed to become entrepreneurs, such as Ciputra campus in Surabaya, or Prasetya Mulya campus in Jakarta. The study by Samsi Haryanto (2014) in STIEBANK Yogyakarta $^{[2]}$ shows that $81 \%$ of students who have been studying for 5 semesters, with 15 credits of entrepreneurial learning materials have their own business. As many as $54 \%$ of those who already own the business claim their business development is good. This data proves that it takes learning process with situation that support to grow entrepreneur spirit.

The results study of Esti Dwi Rinawiyanti and Linda Herawati Gunawan $(2015)^{[3]}$ on Entrepreneurship and Innovation Learning (EIL) in universities that hold multi disciplines in Surabaya showed that $96.8 \%$ of students stated the importance of entrepreneurship courses in universities. As many as $55.3 \%$ of active participants of EIL courses come from the Faculty of Engineering. This data also shows that interest in entrepreneurship is not only from students who pursue the field of economics and business.

The government has supported efforts to develop entrepreneurship in universities through Presidential Instruction No. 4, 1995 with the "The National Movement to Socializes and Cultivates Entrepreneurship"[4]. This movement was followed by the Directorate General of Higher Education (DGHE/DIKTI) in 2009 which requires universities to enter entrepreneurship courses as compulsory subjects in 2 semester. More real movements were undertaken by the Directorate General of Higher Education and University Student of Kemenristek Dikti for the last 4 years (2015-2018) who allocated funding to finance various entrepreneurship programs for students such as: Entrepreneurship Workshop, Integrated Work Study Program, Student Business Competition, Student Entrepreneurship Expo, and Program Student Entrepreneur. The important question to ask is, how effectively can these efforts stimulate students so that they are exposed to entrepreneurship? Universities remain dependable as the right institutions to facilitate learning and provide a supportive environment.

Higher education plays a very strategic role in the development of human resources that can raise the life of the Indonesian nation apart from poverty ${ }^{[5]}$. Law No. 20 of 2003 on the National Education System has provided national education direction, objectives and missions. Higher education is devoted to the benefit of improving human living standards ${ }^{[6]}$. Furthermore, Law No. 12 of 2012 on Higher Education has given autonomy to universities to freely develop the contents of learning with its own advantages as reflected from the curriculum which is used as guidelines to implement education ${ }^{[7]}$.

Universitas Respati Indonesia (URINDO) in Jakarta is one of the private universities located in East Jakarta. Established since 1987, URINDO organizes 14 courses divided into clusters: 1) Health Sciences; 2) Socio-Economic; 3) Agriculture, and 4) Information Technology. Since its establishment until 2017, Entrepreneurship learning is only given to students in the Social Economics Study Program, with a 2-SKS (semester credit system) Entrepreneurship course. With the changes in the field of technology and information marked by the era of disruption in all areas of life, known as the 4.0 era, URINDO is required to be able to compete with other universities in Jakarta by improving the curriculum in order to produce graduates who are able to create job opportunities for him and society.

\section{THE ROLE OF CURRICULUM IN PRODUCING GRADUATES OF ENTREPREUNERS IN HIGHER EDUCATION}

The curriculum is the 'spirit' of college life, as well as software or applications, the curriculum can function well when getting adequate space. The issuance of Presidential Regulation No. 8/2012 on the Indonesian National Qualification Framework (INQF/Kerangka Kualifikasi Nasional Indonesia/ KKNI), has provided guidance on the qualifications of graduates produced by each level of education in universities ${ }^{[8]}$. Followed by the issuance of Permenristek Dikti Number 44 of 2015 on National Standards (NS) of Higher Education/DIKTI, the universities have the flexibility to develop education standards beyond the standards set by Dikti. The standards are: 1) Graduate Competency Standards; 2) Content Standards; 3) Process Standard; 4) Assessment Standards; 5) Lecturer Standard; 6) Standard of Infrastructure Facilities; 7) Management Standards; and 8) Financing Standards. ${ }^{[9]}$

With the autonomy of universities to develop their own curriculum, universities that have the vision of becoming entrepreneurial universities can perform their functions by doing the following: 1) developing climate, process and 
learning substance that inspires, encourages, and helps students develop to their utmost innovation power; 2) to develop the climate, processes and substance of learning that leads to enlightenment to the students so that they are able to see the meaning of the entrepreneur's choice of life; 3) build awareness and understanding of what it takes to become a good entrepreneur; 4) develop a climate, process and substance of learning that can facilitate students preparing themselves to become good entrepreneurs.

The four essences of entrepreneurship education at the university are then designed in a curriculum-shaped document. The process of curriculum engagement begins with setting a graduate profile. The graduate profile is derived from the vision and mission of the university and needs analysis in the community. Based on the painting profile, the standard of entrepreneurship competence is determined in learning achievement (learning outcome), with reference to KKNI level ${ }^{[8]}$.

To support the achievement of learning outcomes, relevant study materials, appropriate strategies / methods, valid assessment instruments to measure learning outcomes, competent lecturers as facilitators, adequacy of infrastructure, good management and most importantly the availability of costs. The process flow of the curriculum can be described as follows ${ }^{[10]}$ : 


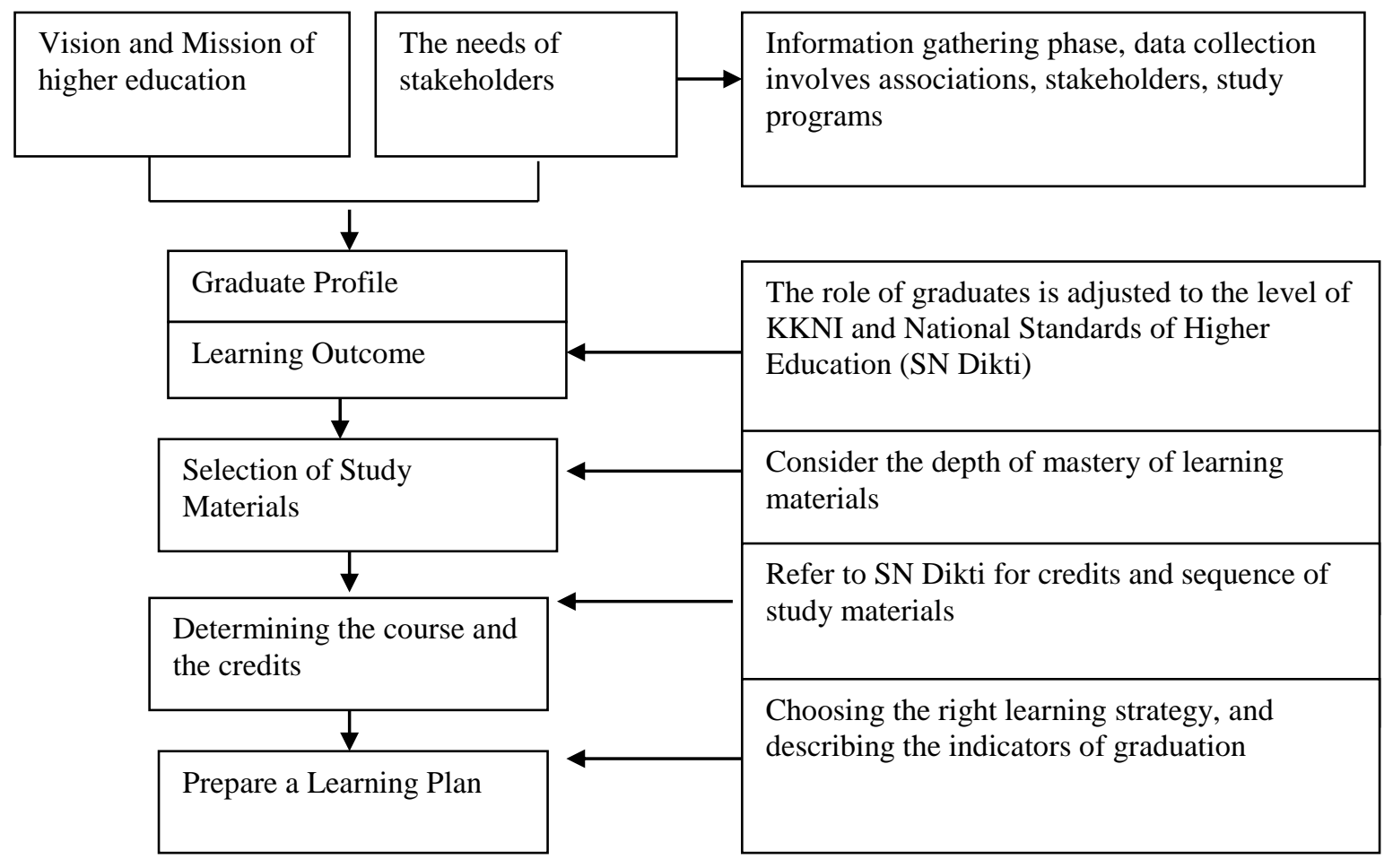

Figure 2.1 Flowchart of Higher Education Curriculum Development

\section{ASSIGNMENT OF GRADUATE PROFILE AND APPROACH TO LEARNING ENTREPRENEURSHIP}

This paper described the process of designing entrepreneurial learning in URINDO Jakarta, referring to the flow chart diagram of the preparation of the KPT (college curriculum):

A. Establishment Vision and Mission of University

In 2016, URINDO set a vision of "Being a university that is able to develop a professional academic community and insightful science, technology, and art as well as entrepreneurial spirit. The determination of such vision changes due to the demands of the university's internal and external environment. Based on that vision, so mission, objectives and targets are prepared. Furthermore, the University's vision, mission, objectives and targets become the reference for all study programs to develop learning and implement quality assurance.

\section{B. Assignment of Graduates and Learning Outcome}

The graduate profile is a description of what role a person can perform when graduating from college. Based on URINDO's new vision, we add a new profile of URINDO graduates to become Entrepreneur. Graduate Profile is described further statement to pair with KKNI and SN Dikti discourses, which can be described as follows ${ }^{[8]}$ :

\section{PROFILE OF} GRADUATES

(along with its

Description)

self-employment

(Businessmen who run their own business ideas independently)

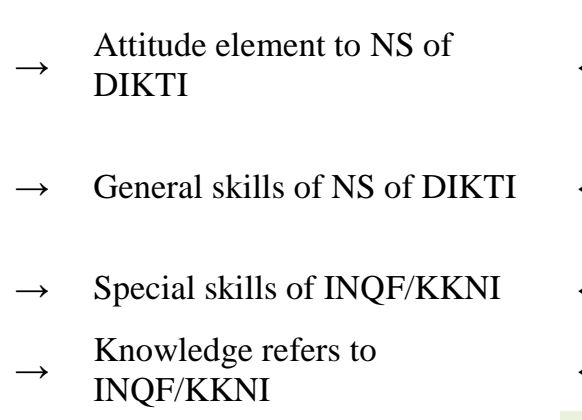

Add in accordance with

$\leftarrow$ excellence / distinctive course of study

Add in accordance with

$\leftarrow$ excellence / distinctive course of study

Use level indicator as reference LOG Description

Use level indicator as reference LOG Description 
Based on the above flow, it can be formulated Achievement of Study Subjects (ASS), which refers to the Learning Outcome Graduate (LOG) for learning in universities, graduates of undergraduate programs, with Entrepreneurship courses as components therein, as follows:

\begin{tabular}{|c|c|}
\hline \multicolumn{2}{|r|}{ 1. ATTITUDE } \\
\hline 1 & Be cautious of God Almighty and able to show a religious attitude. \\
\hline 2 & Uphold the value of humanity in carrying out duties based on religion, morals, and ethics. \\
\hline 3 & $\begin{array}{l}\text { Contributing to improving the quality of life of society, nation, state, and progress of civilization based on } \\
\text { Pancasila. }\end{array}$ \\
\hline 4 & $\begin{array}{l}\text { Serve as a proud citizen and love of the homeland, has nationalism and a sense of responsibility to the state } \\
\text { and nation. }\end{array}$ \\
\hline 5 & $\begin{array}{l}\text { Respect the diversity of cultures, religions, and beliefs, as well as the original opinions or findings of } \\
\text { others. }\end{array}$ \\
\hline 6 & Working together and having social sensitivity and concern for society and environment \\
\hline 7 & Obey the law and discipline in social life and state \\
\hline 8 & Internalizing the spirit of independence, struggle, and \\
\hline 9 & Honest and commitment \\
\hline \multicolumn{2}{|r|}{$\begin{array}{l}\text { Description: the numbers 1-8 (attitudinal elements in NS of DIKTI), number } 9 \text { is the superiority of the study } \\
\text { program, }\end{array}$} \\
\hline \multicolumn{2}{|r|}{ 2. KNOWLEDGE } \\
\hline 1 & $\begin{array}{l}\text { Mastering the theories, methods, and / or philosophy of entrepreneurship field systematically obtained } \\
\text { through reasoning in the learning process, student work experience, research and / or community service } \\
\text { related to self-employment learning. }\end{array}$ \\
\hline 2 & Mastering the concepts and techniques of developing a business plan and teaching it in operational action. \\
\hline 3 & $\begin{array}{l}\text { Mastering the rules, principles and techniques of cross-functional communication, organizational level, and } \\
\text { culture }\end{array}$ \\
\hline \multicolumn{2}{|r|}{ Description Knowledge level undergraduate refers to NS of DIKTI } \\
\hline \multicolumn{2}{|r|}{ 3. GENERAL SKILLS } \\
\hline 1 & $\begin{array}{l}\text { Able to apply logical, critical, systematic, and innovative thinking in the context of developing the } \\
\text { implementation of science and technology that cares and implements the humanities value appropriate to } \\
\text { its area of expertise. }\end{array}$ \\
\hline 2 & Able to demonstrate independent performance, quality, and measurable \\
\hline 3 & $\begin{array}{l}\text { Able to examine the implications of the development or implementation of the science of technology that } \\
\text { concerns and implements the value of humanities in accordance with the field of expertise based on rules, } \\
\text { procedures and scientific ethics in order to produce solutions, ideas, designs, or art criticism, preparing } \\
\text { scientific descriptions of the study in the form of thesis or final report and upload it on the college page. }\end{array}$ \\
\hline 4 & $\begin{array}{l}\text { Prepare a scientific description of the results of the above study in the form of a thesis or final report, and } \\
\text { upload it on the college page. }\end{array}$ \\
\hline 5 & $\begin{array}{l}\text { Be able to make informed decisions in the context of problem solving in the area of expertise, based on the } \\
\text { results of information and data analysis. }\end{array}$ \\
\hline 6 & $\begin{array}{l}\text { Able to maintain and develop networking with colleague counselors, colleagues both inside and outside the } \\
\text { university }\end{array}$ \\
\hline 7 & $\begin{array}{l}\text { Be able to take responsibility for the achievement of group work and perform supervision and evaluation } \\
\text { of work completion assigned to workers who are under their responsibility. }\end{array}$ \\
\hline 8 & $\begin{array}{l}\text { Able to conduct self-evaluation process to work group under its responsibility, and able to manage learning } \\
\text { independently. }\end{array}$ \\
\hline 9 & Able to document, store, secure, and rediscover data to ensure validity and prevent plagiarism. \\
\hline \multicolumn{2}{|r|}{ Undergraduate general skill (1-9) adopt NS of DIKTI } \\
\hline \multicolumn{2}{|c|}{ 4. SPECIAL SKILLS } \\
\hline 1 & $\begin{array}{l}\text { Able to carry out the functions of marketing, human resource development, finance, and implementing } \\
\text { entrepreneurial strategies. }\end{array}$ \\
\hline 2 & $\begin{array}{l}\text { Able to prepare a business plan by developing a strategy based on the current situation and business } \\
\text { conditions. }\end{array}$ \\
\hline 3 & Able to make decisions for business rescue and development with various methods. \\
\hline
\end{tabular}

Based on these components, the formulation of learning achievement of Entrepreneurship in URINDO is as follows:
"Able to create business concepts that can be run on their own or with other partner based on learning experiences through preneur-tour, figures 
that have been successful, and make products that the market needs."

\section{MATERIALS OF ENTREPRENEURSHIP ENTERPRISES}

Based on the formulation of learning achievements that have been described, including components of Attitudes, Knowledge, General skill and Special skill, aligned with level 6 KKNI, it can be made the design of learning Entrepreneurship as follows:

\begin{tabular}{|c|c|c|c|c|}
\hline No. & Expected capability & Study Materials & Learning materials & Learning strategies \\
\hline 1. & $\begin{array}{l}\text { Being able to choose a business } \\
\text { option to try is based on the } \\
\text { experience of the field visit. }\end{array}$ & Preneur Tour & $\begin{array}{l}\text { Observation of } \\
\text { participants in the } \\
\text { service industry, } \\
\text { culinary, fashion, } \\
\text { and lifestyle. }\end{array}$ & Inquiry \\
\hline 2 & $\begin{array}{l}\text { Able to design and demonstrate/ } \\
\text { market the test product that has been } \\
\text { done }\end{array}$ & $\begin{array}{l}\text { Expo/products } \\
\text { exhibition }\end{array}$ & $\begin{array}{l}\text { Marketing, } \\
\text { technical product } \\
\text { packaging, } \\
\text { communication } \\
\text { strategy, } \\
\text { advertising design } \\
\text { through social } \\
\text { media, } \\
\text { content message. }\end{array}$ & Contextual \\
\hline 3 & $\begin{array}{l}\text { Able to work with partners in running } \\
\text { a business. }\end{array}$ & collaboration & $\begin{array}{l}\text { Cooperation } \\
\text { agreement, profit } \\
\text { sharing, } \\
\text { franchising, brands } \\
\text { trade, patent }\end{array}$ & contextual \\
\hline 4 & $\begin{array}{l}\text { Able to organize group seminars to } \\
\text { evaluate the work of individuals / } \\
\text { groups }\end{array}$ & Success Story & $\begin{array}{l}\text { Learn from } \\
\text { successful and } \\
\text { failed figures } \\
\text { through seminar } \\
\text { forums }\end{array}$ & $\begin{array}{l}\text { Collaborative } \\
\text { learning and small } \\
\text { group discussion. }\end{array}$ \\
\hline 5 & $\begin{array}{l}\text { Able to utilize online applications to } \\
\text { sell products }\end{array}$ & Organization & $\begin{array}{l}\text { SMEs, Banking, } \\
\text { virtual services, } \\
\text { online application } \\
\text { of marketing } \\
\text { services }\end{array}$ & $\begin{array}{l}\text { Collaborative } \\
\text { learning and small } \\
\text { group discussion }\end{array}$ \\
\hline
\end{tabular}

\section{CONCLUSIONS AND RECOMMENDATIONS}

\section{A. Conclusions}

Based on the stages of designing entrepreneurial learning that has been done, in an effort to achieve the university vision, it can be made the following conclusions:

1. The implementation of entrepreneurial learning requires adequate means to support the learning process.

2. Entrepreneurial study materials should be up-dated according to changing circumstances.
3. Entrepreneurship learning strategy should provide real experience to students who are able to arouse entrepreneur interest.

4. Lecturer as a facilitator should provide flexibility of students in creating and innovating.

B. Recommendations:

1. The university must provide an entrepreneurship learning facility in the form of a place that can be used to conduct product exhibition and product test to the consumer, for example exhibition room of student creation and innovation product. 
2. The university's management is expected to facilitate students with real entrepreneurship practices such as managing the campus canteen.

3. The university should improve the ability of the lecturers as facilitators of entrepreneurial learning.

4. Entrepreneurship courses are required for all URINDO students as compulsory subjects.

5. This trial of entrepreneurial learning needs to be improved in terms of concept and content of learning.

\section{ACKNOWLEDGEMENT}

The Author wish to thank to Professor Tri Budi W. Rahardjo as Rector of Universitas Respati Indonesia for her support in designing entrepreneurship learning for student as new vision of university.

\section{REFERENCES}

[1] Indonesia PDDikti Kemenristik Dikti, 2017.
[2] Higher Education Stastitical Year Book 2017.

[3] Haryanto, Samsi. 2014. Entrepreneurship Learning Model in Universities (Case Study at STIEBANK Yogyakarta. STIEBBANK Yogyakarta). Journal EBBANK Vo. 5 No.2 55-60, December, 2014.

[4] Rimayanti, Esti Dwi dan Herawati Gunawan Linda. 2015. Study of Entrepreneurship Learning at University. Journal Entrepreneur and Entrepreneurship Vo. 4 No. 1,2 (2015).

[5] President of Republik Indonesia instruction Nomor 4- 1995 regarding national movement of community and culture of entrepreneurship.

[6] Tilaar, H.A.R. 2008. National Awakened Educational Policy.LM. UNJ Jakarta.

[7] Bok.Derek. 1982. Beyond Ivory Tower, Harvard University Press, Boston. USA

[8] Republic of Indonesia Law no 12- 2012, on higher eduation.

[9] Presidential rule of RI no. 8- 2012. Indonesia National Qualification Framework (KKNI).

[10] Ministy Rule of Research and Technology of Higher Education No. 44 -2015, on National Standards of Higher Education.

[11] Guideline of Curriculum prepation of higher education, 2016. Directorate of Learning and Students, Ministry of Research and Techonolgy of Higher Education. 